\title{
腎癌における制癌剤効果増強について
}

\begin{tabular}{lllllll}
\multicolumn{8}{c}{ 岐阜大学医学部泌尿器科学教室 (主任 : 河田幸道教授) } \\
岡野 & 学 & 川本 正吾 & 根笹 & 信一 & 玉木 & 正義 \\
江原 & 英俊 & 山田伸一郎 & 出口 & 隆 & 河田 & 幸道
\end{tabular}

\section{ENHANCEMENT OF CYTOTOXIC EFFECT OF ANTICANCER AGENTS ON RENAL CELL CARCINOMA}

\author{
Manabu Okano, Syogo Kawamoto, Shinichi Nezasa, Masayoshi Tamaki, \\ Hidetoshi Ehara, Shinichirou Yamada, Takashi Deguchi \\ and Yukimichi Kawada \\ Department of Urology, Gifu University School of Medicine \\ (Director: Prof. Y. Kawada)
}

(Background) Human renal adenocarcinomas do not adequately respond to cancer chemotherapy. Their multidrug resistance is mainly confered by the P-glycoprotein (P-gp). In this study, we analyzed effects of P-gp modulators on enhancement of anticancer activities against human renal cell carcinomas.

(Methods) ACHN/ADM human renal adenocarcinoma cells with a high level expression of $\mathrm{P}$-gp and 28 surgical specimens of renal cell adenocarcinomas were recruited. Adriamycin (ADM) and vinblastin (VLB) were used as anticancer drugs, and verapamil (Ver) and cyclosporin A (CsA) were as P-gp modulators. The chemosensitivity was determined by the ATP-assay.

(Results) Ver and CsA exhibited 1.5-fold and 6-fold increase, respectively, in the anticancer activities of ADM against ACHN/ADM cells. The anticancer activities of VLB were also enhanced by the modulators; 7 -fold for Ver and 11-fold for CsA. In the chemosensitivity test of clinical specimens, the cancer for which the viability of the cells assessed by the ATP-assay was $50 \%$ or less than $50 \%$ after exposure to the anticancer drug with or without a P-gp modulator was defined as sensitive to the drug. Of the 14 clinical specimens exposed to anticancer durgs wihtout Ver, only 3 tumors and 1 tumor were sensitive to ADM and VLB, respectively, whereas with Ver, 6 tumors and 4 tumors were sensitive to ADM and VLB, respectively. Of the other 14 clinical specimens exposed to anticancer drugs without CsA, only 3 tumors and no tumor were sensitive to $\mathrm{ADM}$ and $\mathrm{VLB}$, respectively, whereas, with $\mathrm{CsA}, 9$ tumors and 6 tumors were sensitive to $\mathrm{ADM}$ and VLB, respectively.

(Conclusion) This study indicate that Ver and CsA have effects on enhancement of the anticancer activities of ADM and VLB against human renal adenocarcinomas. The addition of Ver or CsA to chemotherapy will be a potential circumvention of P-gp-mediated multidrug resistance of renal cell adenocarcinomas.

Key words: renal cell carcinoma, verapamil, cyclosporin A

要旨：(背景と目的）腎細胞癌は一般に化学療法に充分な反応がみられないが，その原因として Pglycoprotein (P-gp) の発現による多剤耐性が注目されている. 本検討で, われわれは P-gp 而性克服薬 剤によるヒト腎細胞癌に対する制癌剤効果の増強を in vitro で検討した.

(方法) P-gp 高度発現ヒ卜腎細胞癌由来培養株 ACHN/ADM および28例の腎細胞癌患者から手術的 に摘出した臨床検体を対象として検討した。制癌剤としては adriamycin (ADM) と vinblastin (VLB) 
を使用した．－gp 耐性克服薬剤としては verapamil（Ver）および cyclosporin A（CsA）を用いたが， それぞれの濃度は ACHN/ADM の発育に影響を与えない Ver $2.5 \mu \mathrm{g} / \mathrm{ml}, \mathrm{CsA} 0.5 \mu \mathrm{g} / \mathrm{ml}$ とした. また, 制癌剤感受性試験は ATP 法にて行った。

(結果) $\mathrm{ACHN} / \mathrm{ADM}$ 株に対して ADM ではVer および CsA によりそれぞれ1.5倍， 6 倍の制癌効果 増強を認めた。また，VLBにおいてもさそれぞれ 7 倍，11倍と制癌効果の増強が同様にみられた。臨床 検体に対する制癌剤感受性試験では P-gp 耐性克服剤の併用の有無に関わらず制癌剤に接触後 ATP 法 で50\%以下の細胞活性を示した場合，その薬剤に対して感受性有りと判定した。Ver 併用を検討した臨 床検体14例に対して制癌剤は単独ではそれぞれ ADM で 3 例, VLB で 1 例の感受性しか示さなかった ものの, Ver を併用したところ ADM で 6 例, VLB で 4 例が感受性を示した. CsA 併用を検討した他の 臨床検体14例では制癌剤単独では ADM で 3 例感受性を示し, VLBでは感受性無しであったが, CsA 併 用でそれぞれ 9 例， 6 例の感受性を示した。

（結論）この検討により，腎細胞癌においてはVer または CsA を併用することにより ADM やVLB の制癌効果が増強すると考えられ, P-gpによる多剤耐性の腎細胞癌に対するこれらの臨床応用に期待が 持たれた。

キーワード：腎細胞癌, ベラパミル，シクロスポリン A

\section{緒 言}

腎細胞癌は既存の制癌剤に対して低感受性である がそその原因のひとつとして腎細胞癌では $\mathrm{P}$. glycoprotein (P-gp) が高率に発現している点があげら れる ${ }^{12)}$. このため制癌剤の効果を増強する目的とし て, P-gp による細胞内からの制癌剂排出作用を阻害 し, 制癌剤濃度を高める作用を有する薬剤の併用が考 えられ, 一部臨床にも応用されている(3) 6). 今回我久 は, 腎細胞癌の効果的化学療法の開発を目的として P-gp 高度発現七ト腎細胞癌由来培養株および臨床検 体を用い, adriamycin (ADM) および vinblastine (VLB) に対する P-gp 而性克服薬剤の殺細胞効果増強 について検討した。

\section{対象および方法}

ヒト腎癌細胞由来培養株として当教室で継代中の $\mathrm{ACHN}$ 細胞と, $\mathrm{ACHN}$ 細胞を $\mathrm{ADM}$ 加培養液にて継 代し得られた ADM 而性株 $\mathrm{ACHN} / \mathrm{ADM}$ を用いた。 $\mathrm{ACHN} / \mathrm{ADM}$ の P-gp 産生能については C219抗体を 用いた Western blotting 法にて検討した ${ }^{7)}$. 107個の細

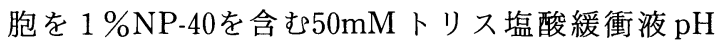
8.0中で溶解し, $1,500 \mathrm{~g} 5$ 分間遠心後に得られた上清 を外膜蛋白抽出分画として用いた. Sodium dodecyl sulfate-polyacrylamide ゲルにて電気泳動しニトロセ ルロース膜に転写し C 219 抗体と反応させた。シグナル の検出には化学反応を利用する ECL キット (Amersham）を用いた。また，臨床材料は28例の腎細胞癌患 者より手術時に採取した28腎腫瘍組織を使用した。培 養株および臨床材料に対する制癌剤および P-gp 而性
克服薬剂の殺細胞効果の測定は細胞数と細胞内 ATP 量の直線関係を利用した山田ら ${ }^{8)}$ の方法に従って ATP 法にて行った。摘出腫瘍組織は細切し, Hanks 液 に浮遊し, Dispase (protease) 含有 DM-160培地中で $37^{\circ} \mathrm{C} 120$ 分 incubate した。これをナイロンメッシュに て濾過し, $1,200 \mathrm{rpm}, 10$ 分間遠心し上清を除去し, $15 \%$ FCS 加 DM-160に浮遊混和した。この細胞浸遊液を 24 well plate に分注後薬剤を添加した. 制癌剤として $\mathrm{VLB}$ および ADM を，P-gp 耐性克服薬棛として前期 14例には verapamil (Ver) を後期14例には cyclosporin A (CsA) を使用し, 薬剤添加後 $5 \% \mathrm{CO}_{2}, 37^{\circ} \mathrm{C}$ にて 3 日間培養後 ATP 量を bioluminescence 法にて測定 した ${ }^{8)}$. Survival rateは薬剤添加細胞の ATP 量を control である薬郕非添加細胞の ATP 量で除した百 分率で表し，臨床材料においては $50 \%$ 以下を感受性有 りとしだ).

\section{結果}

1. $\mathrm{ACHN} / \mathrm{ADM}$ に対する制癌剤感受性および $\mathrm{P}$. gp 発現レベルの検討

$\mathrm{ADM}$ と VLB の $\mathrm{ACHN}$ および ACHN/ADMに 対する殺細胞曲線を Fig. 1 に示した。 $\mathrm{IC}_{50}$ では $\mathrm{ACHN} / \mathrm{ADM}$ は ACHN に比べADM に対して13倍, VLB に対して89倍の耐性がみられた。 Western blotting 法による検討では P-gp である $170 \mathrm{kD}$ の蛋白の描 出が ACHN ではみられぬものの ACHN/ADM では 16倍希釈 $(100 \times 1 / 16 \mu \mathrm{g})$ まで観察され，P-gp は ACHN/ADM で高く発現した (Fig. 2).

2. P-gp 耐性克服薬剤の殺細胞効果の検討 
Fig. 1 Survival curves of ACHN and ACHN/ADM cells treated with ADM or VLB
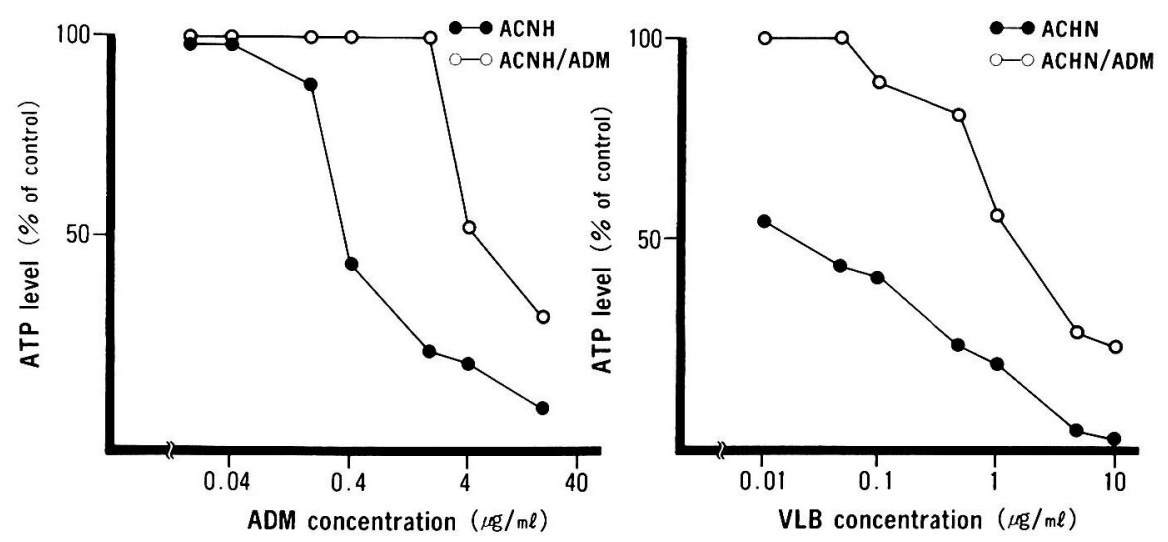

Fig. 2 Western blot hybridization analysis of ACHN and ACHN/ADM cells.

The extracted protein was loaded on lanes, as follows; lane 1, control (bovine adrenal gland); lane 2, ACHN $100 \mu \mathrm{g}$; lane 3, ACHN/ADM 100 $\mu \mathrm{g}$; lane $4,100 \times 1 / 2 \mu \mathrm{g}$; lane $5,100 \times 1 / 4 \mu \mathrm{g}$; lane $6,100 \times 1 / 8 \mu \mathrm{g} ;$ lane $7,100 \times 1 / 16 \mu \mathrm{g} ;$ lane $8,100 \times$ $1 / 32 \mu \mathrm{g}$.

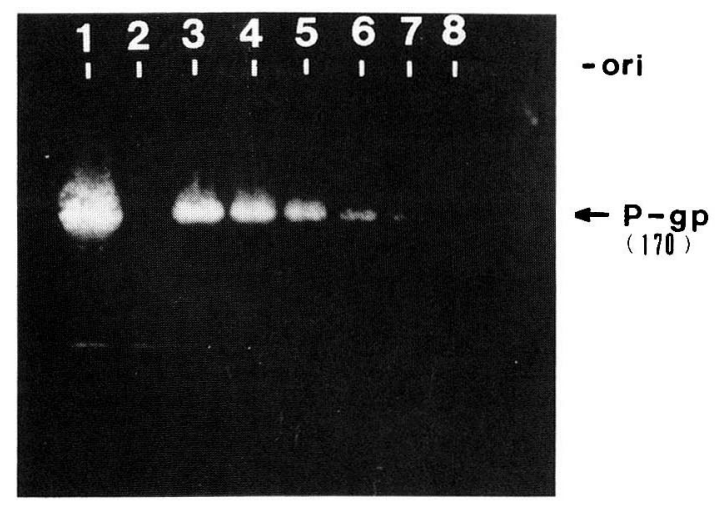

$\mathrm{ACHN} / \mathrm{ADM}$ に対するVer およびCsAの殺細胞 効果を検討したところ, Ver は $5 \mu \mathrm{g} / \mathrm{ml}$ 以下, CsA は1 $\mu \mathrm{g} / \mathrm{ml}$ 以下では両株に影響をあたえず，今後の制癌剤 との併用の検討に際してはそれぞれの濃度を $2.5 \mu \mathrm{g} /$ $\mathrm{ml}$ および $0.5 \mu \mathrm{g} / \mathrm{ml}$ として行うこととした.

3. Ver および CsA 併用による制癌刘の殺細胞効果 の検討

$\mathrm{ACHN} / \mathrm{ADM}$ に対するADM とVLBのVer およ びCsA 併用時の殺細胞効果をTable 1 に示した。 $\mathrm{ADM}$ はVer を併用した場合 $\mathrm{IC}_{50}$ は $3.3 \mu \mathrm{g} / \mathrm{ml}$ であり 単独に比べ約 $2 / 3 に$ 低下していた。 また, 通常使用量時 の血中ピーク值である lpeak plasma concentration （ppc）に相当する $0.4 \mu \mathrm{g} / \mathrm{ml}$ における survival rate は 単独では100\%であるものの併用時では $84 \%$ と低下し ていた。同様に, VLBにおいても併用時の $\mathrm{IC}_{50}$ は 0.16 $\mu \mathrm{g} / \mathrm{ml}$ であり単独に比べ約 $1 / 7 に$ 低下しておう，1ppc に相当する $0.1 \mu \mathrm{g} / \mathrm{ml}$ における survival rate は単独 で84\%であるものの併用時では $68 \%$ であった。また，

Table 1 Effect of verapamil and cyclosporin $\mathrm{A}$ on the anticancer drug activity against the ACHN/ADM cells

\begin{tabular}{c|c|c|c|c}
\hline & \multicolumn{2}{|c|}{$\mathrm{IC}_{50}(\mu \mathrm{g} / \mathrm{ml})$} & \multicolumn{2}{c}{ Survival rate(\%) } \\
\cline { 2 - 5 } & $\mathrm{ADM}$ & $\mathrm{VLB}$ & $\begin{array}{c}\mathrm{ADM} \\
(0.4 \mu \mathrm{g} / \mathrm{ml}) *\end{array}$ & $\begin{array}{c}\mathrm{VLB} \\
(0.1 \mu \mathrm{g} / \mathrm{ml}) *\end{array}$ \\
\hline $\begin{array}{c}\text { Anticancer drug alone } \\
\text { Anticancer drug with: }\end{array}$ & 4.5 & 1.2 & 100 & 84 \\
Verapamil & 3.3 & 0.16 & 84 & 68 \\
Cyclosporin A & 0.75 & 0.11 & 62 & 52 \\
\hline \multicolumn{3}{c}{${ }^{*}$ corresponded to peak plasma concentration }
\end{tabular}


Table 2 Grade and stage of clinical specimens

\begin{tabular}{l|c|c}
\hline & $\begin{array}{c}\text { Group 1 } \\
\text { (Verapamil) }\end{array}$ & $\begin{array}{c}\text { Group 2 } \\
\text { (Cyclosporin A) }\end{array}$ \\
\hline Grade 1 & 8 & 1 \\
Grade 2 & 5 & 12 \\
Unknown & 1 & 1 \\
\hline Stage pT2 & 12 & 10 \\
pT3 & 2 & 4 \\
\hline
\end{tabular}

CsA 併用時においても $\mathrm{IC}_{50}$ は $\mathrm{ADM}$ で約 $1 / 6, \mathrm{VLB}$ で 約 $1 / 11$ に低下した. ADM $0.4 \mu \mathrm{g} / \mathrm{ml}$, VLB $0.1 \mu \mathrm{g} / \mathrm{ml}$ の濃度における survival rate は ADM で単独の $100 \%$ から併用時 $62 \%$, VLB で $84 \%$ から $52 \%$ へと低下し た. 臨床検体における併用効果の検討は Table 2 に示 す28例の primary cultureで行ったが, Ver および CsA それぞれの併用で14例ずつ使用した. 両群を比べ ると悪性度は CsA 群で Grade 2の症例が多く認めら れたが病期には差を認めず，ADM およびVLBに感 受性を認めた症例数もほぼ同じであった。ADM 0.4 $\mu \mathrm{g} / \mathrm{ml}, \mathrm{VLB} 0.1 \mu \mathrm{g} / \mathrm{ml}$ の濃度での survival rate は Ver 併用の場合 ADM では単独で $66.5 \%$ から併用時 $51.6 \%$ と有意に低下し ( $\mathrm{t}$ 検定, $\mathrm{p}=0.0003), \mathrm{VLB}$ で は単独で $74.3 \%$ から併用時 $62.6 \%$ へと低下した（ $\mathrm{p}=$ 0.0012). 感受性を認めた症例は ADM で 6 例, VLB で 4 例あり, 単独の場合に比べともに 3 例ずつ増加し
た (Fig. 3)。CsA 併用の場合 ADM では単独で56.6\% から併用時 $41.5 \%$ へと低下し $(\mathrm{p}=0.0009)$, VLBでは 単独で $72.4 \%$ から併用時 $53.0 \%$ へと低下した（p= 0.0000)。感受性を認めた症例は ADM で 9 例, VLB で 6 例ありそれぞれで 6 例ずつ増加した（Fig. 4).

\section{考 察}

近年, 様々な制癌剤の開発が進められているものの, その実用化までには多くの経費と時間が必要である. そのため, 既存の薬剤を用いて投与方法や併用療法を 検討し, その有効性向上を図ることも臨床上非常に重 要な課題である. 泌尿器科腫瘍のうちでは精巣腫瘍, 尿路上皮腫瘍は制癌剤に対して感受性が高いものの, 腎細胞癌では現在治療の中心であるインターフェロン をもってしても有効性はせいぜい $20 \%$ 程度であ $3^{9110)}$. 腎細胞癌の制癌剤に対する低感受性の原因と してはいくつもの因子が複雑に関与していると考えら れるが, 特に制癌剤の能動的排出ポンプである P-gp が高率に発現している点が注目される. 今回基礎的検 討に使用した P-gp 高度発現 ADM 耐性株である $\mathrm{ACHN} / \mathrm{ADM}$ は細胞内 $\mathrm{ADM}$ の蓄積量を蛍光量でみ たところ ACHN に比べ著しく低下しており ${ }^{11)} \mathrm{P}-\mathrm{gp}$ が ADM 而性の主因と考えられる。また，臨床例にお

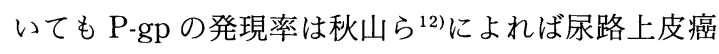
の $22 \%$ に対して腎細胞癌では $87 \%$ と高率であり，本検 討中においても reverse transcriptase-polymerase

Fig. 3 Survival rates of primary culture cells treated with $0.4 \mu \mathrm{g} / \mathrm{ml}$ of ADM or $0.1 \mu \mathrm{g} / \mathrm{ml}$ of $\mathrm{VLB}$ alone or in the presence of $2.5 \mu \mathrm{g} / \mathrm{ml}$ of verapamil
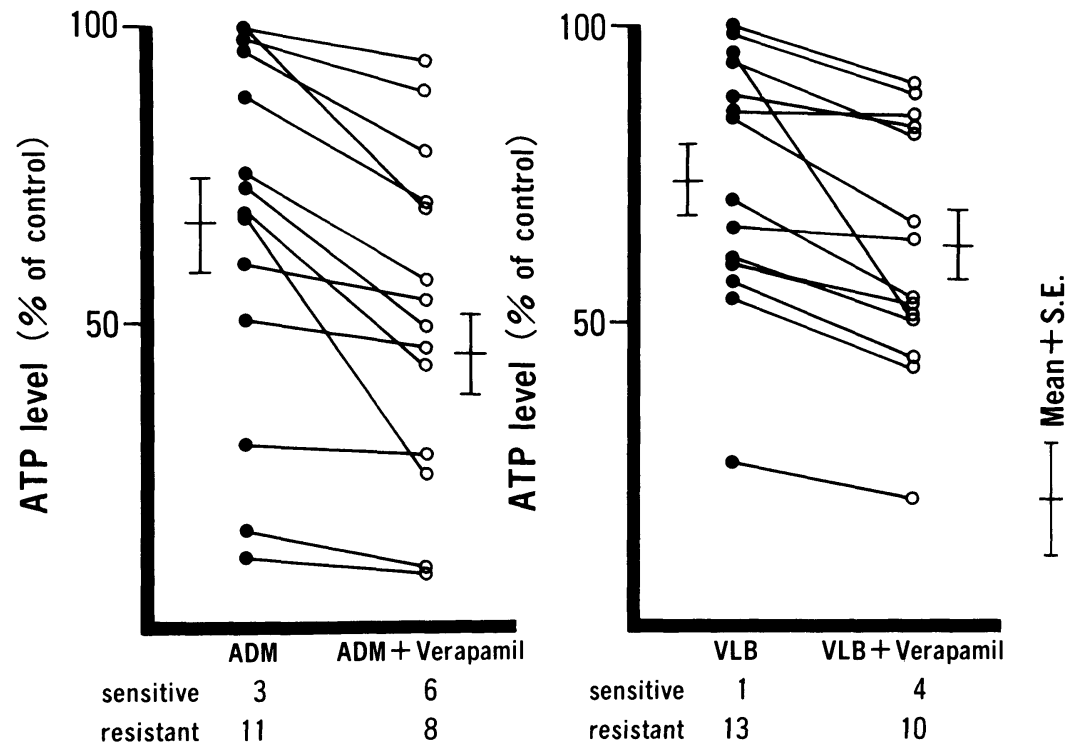
Fig. 4 Survival rates of primary culture cells treated with $0.4 \mu \mathrm{g} / \mathrm{ml}$ of ADM or $0.1 \mu \mathrm{g} / \mathrm{ml}$ of VLB alone or in the presence of $0.5 \mu \mathrm{g} / \mathrm{ml}$ of cyclosporin A

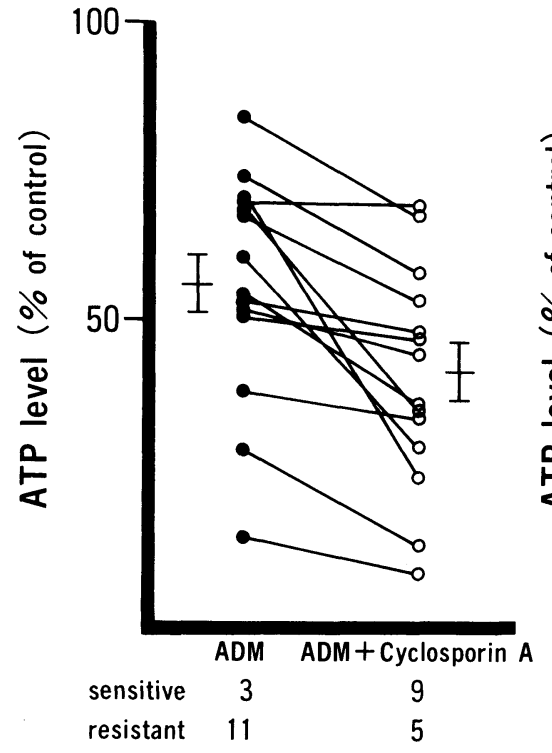

chain reaction 法により P-gp mRNA の発現の検討が 可能であった腎細胞癌13例では全例陽性であった ${ }^{13)}$. このため P-gp が関与した耐性機構を克服することは 腎細胞癌に対する制癌作用を向上させるうえで非常に 有用性が期待される。

これまでにも P-gpによる耐性を克服する目的で, P-gp と結合しその制癌剂の細胞外排出作用を阻害し, 細胞内の制癌剤濃度を高める働きを持つ様々な薬剤が 試みられている ${ }^{14)}$. 我々はカルシウム拮抗薬である Ver および免疫抑制剤であるCsA を制癌剤と併用し た。両剤は川本らによる ACHN/ADMにおける検討 では ADM の蓄積量を併用しない場合に比べ，いずれ も約 3 倍増加させるとのことであり ${ }^{11)}$, 今回, $\mathrm{ACHN} /$ ADM に対するその制癌効果を ATP 法にて検討した ところ,ともにその増強が確認された。また, ACHN/ ADM はVLB に対し交差耐性を示し, Ver と CsAに より ADM 同様にかなりの程度の制癌剤感受性の reverse がみられた。今回用いた ATP 法は生体のエネ ルギー源である ATP を測定する制癌剤感受性試験で あるが, 癌細胞の制癌剂処理後においても生細胞数と 有意の相関を示し細胞内 ATP 量が cell viabilityの 良い指標であることを利用したものである ${ }^{8)}$.

また, 臨床検体においても感受性のみられなかった 症例がVer を併用することで ADM, VLB ともに 3 例ずつ, CsA を併用することで 6 例ずつ感受性有りへ



と変動し効果の増強がみられた. 感受性の有無の判定 に関しては何\%で判断するかは議論のあるところであ るが, 地主ら ${ }^{15)}$ の消化器癌の検討, 山田ら ${ }^{8)}$ の尿路性器 腫瘍の検討に従い, 今回は $50 \%$ を境界とした。

Ver と CsAを比較すると ACHN/ADMでは $\mathrm{ADM}, \mathrm{VLB}$ ともに CsA で reverse の程度が著明で あった。臨床検体では耐性克服薬を併用しない場合， 両群間には感受性症例数の差はほとんどみられぬもの の, 併用した場合, 感受性側へ変動した症例は CsA 併 用で多く, survival rateの平均をみても Ver 併用では ADM で14.9\%, VLB で11.7\%の低下に比べ, CsA 併 用ではそれぞれ $15.1 \% ， 19.4 \%$ とり低下していた。 Ver とCsAの作用機序の差についてはP-gp に対す る binding siteの違いとも推測されており ${ }^{16)}$, それが 効果の差を生む可能性があり今後より一層の解明が待 たれるところである。また，耐性克服薬剤による殺細 胞効果の増強は ADM に比べVLBでより顕著にみら れ, VLB はその耐性機序の中で P-gp の影響がより大 きい薬剤と考えられた. P-gp 耐性克服薬凨を併用して も $\mathrm{ACHN} / \mathrm{ADM}$ の制癌剤感受性は ACHN のそれに は完全には reverse しないこと, 臨床検体のなかでも 症例間で感受性の変動に差があることより, 腎細胞癌 の耐性が P-gp だけによるものではなく他の耐性機構 の存在を示唆するものであるが, 症例によっては非常 な効果増強を示すものがあり症例を選べば少なからず 
これらの薬剤が臨床の場においても有用と考えられ る.

現在のところ P-gp 克服薬剤の投与に際してはいく つかの問題点がある。まず第一に全身投与では克服薬 剂濃度を in vitroでの有効濃度にするためにはかなり の投与量を必要とし, その副作用が懸念される. カル シウム拮抗薬であるVer では心血管系への影響が, 免 疫抑制剤である CsA では白血球減少が問題となるが, それに加え正常組織での P-gp の生理機能をも阻害す るため,たとえば胆管上皮における胆汁排泄作用阻害 による高ビリルビン血症などが問題となり, P-gp 耐性 克服薬剤の dose limitting factor のひとつと考えられ $3^{14)}$. このように耐性克服薬の臨床応用には副作用や 効果の点で問題が多いが, 現在これに対して様々な薬 剤で検討が行われている。たとえば以前より抗アレル ギー薬として使用されていたセファランチン17), また 新薬としては心血管系への作用の少ないカルシウム拮 抗薬である R-ベラパミル ${ }^{18)}$, 免疫抑制作用の少ない PSC83319)の他にも，PAK 20012)，L623（N1379） ${ }^{17) な ~}$

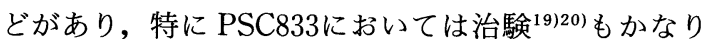
進んでいるようで安全で克服活性の高い薬剤が近い将 来臨床の場で使用されることとなろう. また Dalton ら ${ }^{21)}$ のごとく in vivoにおいては in vitro と同様の高 い薬剤濃度が必要とは限らないとの考えもあり, 可能 な最大投与量で臨床応用してみることも検討に值する と思われる。

P-gp については末だ不明の点も多い. 例えばどの程 度の発現で耐性化してしまうのかという P-gp 量と耐 性度の相関性の有無, 腫瘍組織による特異性やその分 化度による発現の差の有無, また各臓器における本来 の生理機能などである.これらの点が今後究明され, 腎細胞癌をはじめP-gpによる多剂耐性癌治療におけ る効果的で副作用の少ない耐性克服薬剤の早期の臨床 応用が期待される。

\section{結 語}

1. ACHN/ADM ではP-gpの発現の増強がみら れ, $\mathrm{ACHN}$ に比べ $\mathrm{IC}_{50}$ で約13倍耐性化していた。

2. ACHN/ADM はVLB に対して交差耐性を示し た.

3. ACHN/ADM に対してVer を併用した場合, $\mathrm{IC}_{50}$ は $\mathrm{ADM}$ で約 $2 / 3, \mathrm{VLB}$ で1/7に低下した. CsA を 併用した場合それぞれ $1 / 6 ， 1 / 11$ に低下した。

4. Primary culture 28例の検討では感受性を認め た症例は Ver 併用の場合 ADM，VLB ともに 3 例増
加し, CsA 併用の場合ともに 6 例増加し制癌効果の増 強がみられ，今後の臨床応用に期待がもたれた。

稿を終えるにあたり，検体提供に御協力を頂いた当教室 員諸兄ならびに以下の各関連病院泌尿器科の諸先生方に深 謝致します。

岐阜市民病院，県立岐阜病院，羽島市民病院，大垣市民病 院, 県立下呂温泉病院, 高山赤十字病院, 松波総合病院, 平 野総合病院, 木沢記念病院, 大雄会第一病院, 東海記念病院, トヨ夕記念病院，彦根市立病院，長浜赤十字病院.

\section{文献}

1) Kanamaru, H., Kakehi, Y., Yoshida, O., Nakanishi, S., Pastan, I. and Gottesman, M.M. : MDR1 RNA levels in human renal carcinomas : Correlation with grade and prediction of reversal of doxorubicin resistance by quinidine in tumor explants. J. Natl. Cancer Inst., 81, 844849, 1989.

2) Mickisch, G.H., Roehrich, K., Koessig, J., Foster, S., Tschada, R.K. and Alken, P.M. : Mechanism and modulation of multidrug resistance in primary human renal cell carcinoma. J. Urol., 144, 755-759, 1990.

3）本田利雄, 三比和美, 服部理男：多剤耐性となった 再発性非ホジキンリンパ腫に対する Nicardipine と Vinca Alkaloid の併用による治療の試み。A preliminary report. 癌と化学療法, 10, 23302334, 1984.

4）赤沢修吾, 本田敏雄, 三比和美, 三ツ木浩一：カル シウム拮抗剤の併用を試みた Vindesine sulfate, Cis-diammine dichloroplatinum (II)に治療抵抗 性食道癌の 2 症例．癌と化学療法, 11, 943-947, 1984.

5) Benson, A.B. III, Trump, D.L., Koeller, J.M., Egorin, M.I., Olman, E.A., Witte, R.S., Davis, T. E. and Tormey, D.C. : Phase I study of vinblastine and verapamil given by concurrent iv infusion. Cancer Treat. Rep., 69, 795-799, 1985.

6) Ozols, R.F., Cunnion, R.E., Klecker, R.W. Jr., Hamilton, T.C., Ostchega, Y., Parrillo, J.E. and Young, R.C.: Verapamil and adriamycin in the treatment of drug-resistant ovarian cancer patients. J. Clin. Oncol., 5, 641-647, 1987.

7) Nishiyama, K., Shirahama, T., Yoshimura, A., Sumizawa, T., Furukawa, T., IchikawaHaraguchi, M., Akiyama, S. and Ohi, Y.: Expression of the multidrug transporter, Pglycoprotein, in renal and transitional cell carcinomas. Cancer, 71, 3611-3619, 1993.

8）山田伸一郎, 出口 隆, 根笹信一, 玉木正義, 江原 英俊, 岡野 学, 河田幸道: 細胞内 ATP 量を指標 
とした尿路性器腫瘍の抗癌剤感受性試験の検討.

日泌尿会誌，83，2022-2028，1992。

9) Quesada, T.R., Swanson, D.A., Trindada, A. and Guttermann, J.U. : Renal cell carcinoma : Antitumor effect of leukocyte interferon. Cancer Res., 43, 940-947, 1983.

10）里見佳昭, 千賀 裕, 福田百邦, 河合恒夫：インタ ーフェロン療法. 日泌尿会誌, 75, 909-916, 1984.

11）川本正吾, 根笹信一, 西田泰幸, 玉木正義, 山田伸 一郎, 岡野 学, 出口 隆, 河田幸道: 多剂耐性七 卜腎細胞癌由来培養細胞株における制癌剤効果増 強について [abstract]. Proc. Jpn. Cancer Assoc., 53, 662, 1994.

12）秋山伸一：癌細胞の薬剤耐性克服。西日泌尿, 54, 557-559， 1992 .

13）根笹信一, 出口 隆, 川本正吾, 西田泰幸, 山田伸 一郎, 岡野 学, 江原英俊, 玉木正義, 藤広 茂, 栗山 学, 坂 義人, 河田幸道: RT-PCR 法によ る多剂耐性遺伝子 (MDR1) mRNA 発現の検討. J. Jpn. Soc. Cancer Ther., 28, 345, 1993.

14) Leyland-Jones, B., Dalton, W., Fisher, G.A. and Sikic, B.I.: Reversal of multidrug resistance to cancer chemotherapy. Cancer, 72, 34843488, 1993.

15）地主和人，平林直樹，桐原義昌，高上真一，金 隆 史, 頼島 敬, 西山正彦, 野宗義博, 峠 哲哉：消 化器癌に対する ATPassay の臨床的検討. 癌と化 学療法, 17, 2235-2239, 1990.

16) Cardarelli, C.O., Aksentijevich, I., Pastan, I. and Gottesman, M.M.: Differential effect of P. glycoprotein inhibitors on NIH3T3 cells transfected with wild-type (G185) or mutant (V185) multidrug transporters. Cancer Res., 55, $1086-$ 1091, 1995.

17）筧 善行, 清川岳彦, 橋村孝幸, 吉田 修：腎細胞 癌における内因性多剤耐性とその克服. 泌尿紀要, 38, 1319-1324, 1992.

18) Keilhauer, C., Emling, F., Raschak, M., Gries, J. and Schlick, E.: The use of R-verapamil (RVPM) is superior to racemic VPM in breaking multidrug resistance (MDR) of malignant cells [abstract]. Proc. Am. Assoc. Cancer Res., 30, 503, 1989.

19) Keller, R.P., Altermatt, H.J., Nooter, K., Poschmann, G., Laissue, J.A., Bollinger, P. and Hiestand, P.C.: SDZ PSC 833, a nonimmunosupessive cyclosporine: Its potency in overcoming P-glycoprotein-mediated multidrug resistance of murine leukemia. Int. J. Cancer, 50, 593-597, 1992.

20) Boesch, D., Gaveraux, C., Jachez, B., PourtierManzanedo, A., Bollinger, P. and Loor, F.: In vivo circumvention of P-glycoprotein-mediated multidrug resistance of tumor cells with SDZ PSC 833. Cancer Res., 51, 4226-4233, 1991.

21) Dalton, W.S., Grogan, T.M., Meltzer, P.S., Scheper, R.J., Durie, B.G.M., Taylor, C.W., Miller, T. P. and Salmon, S.E. : Drug resistance in multiple myeloma and non-Hodgikin's lymphoma: Detection of P-glycoprotein and potential circumvention by addition of verapamil to chemothrapy. J. Clin. Oncol., 7, 415-424, 1989. (1995年7月7日受付，1996年5月13日受理) 